\title{
Rhizobium multihospitium sp. nov., isolated from multiple legume species native of Xinjiang, China
}

\section{Correspondence Wen Xin Chen wenxin@cau.edu.cn}

\author{
Tian Xu Han, ${ }^{1}$ En Tao Wang, ${ }^{1,2}$ Li Juan Wu, ${ }^{1}$ Wen Feng Chen, ${ }^{1}$ \\ Jin Gang Gu, ${ }^{3}$ Chun Tao Gu, ${ }^{1}$ Chang Fu Tian ${ }^{1}$ and Wen Xin Chen ${ }^{1}$
}

\footnotetext{
${ }^{1}$ Key Laboratory of Agro-Microbial Resource and Application, Ministry of Agriculture/College of Biological Sciences, China Agricultural University, Beijing 100094, PR China

${ }^{2}$ Departamento de Microbiología, Escuela Nacional de Ciencias Biológicas, Instituto Politécnico Nacional, 11340 México D.F., México

${ }^{3}$ The Institute of Agricultural Resources and Regional Planning of Chinese Academy of Agricultural Sciences. Beijing 100081, PR China
}

Thirty-one rhizobial strains isolated from nodules of legumes native of Xinjiang, China, were characterized. These strains were classified as belonging to the genus Rhizobium based on amplified 16S rDNA restriction analysis (ARDRA). The strains were distinguished from recognized Rhizobium species using analysis of 16S-23S rDNA intergenic spacers (IGS-RFLP), SDSPAGE analysis of whole proteins and BOX-PCR; the test strains always formed a distinct cluster with patterns that were quite different from those of the reference rhizobial strains used.

According to the phylogenetic analysis based on the 16S rRNA gene, the test strains belonged to the genus Rhizobium, with Rhizobium tropici, Rhizobium rhizogenes and Rhizobium lusitanum as the closest related species, with $99.6,99.2$ and $99.4 \%$ sequence similarities, respectively, between the type strains of the three Rhizobium species and strain CCBAU $83401^{\top}$.

Phylogenetic analyses of the representative strains using IGS and atpD, $\operatorname{rec} A$ and $g / n / l$ genes all confirmed the phylogenetic arrangements obtained using the 16S rRNA gene. The DNA-DNA relatedness values between strain CCBAU $83401^{\top}$ and strains CCBAU 83364, CCBAU 83345 and CCBAU 83523 ranged from 80.8 to $100 \%$, showing that they belong to the same species. The DNA-DNA relatedness between strain CCBAU $83401^{\top}$ and $R$. tropici IIB CIAT $899^{\top}, R$. tropici IIA CFN 299, $R$. rhizogenes LMG $150^{\top}$ and $R$. lusitanum $\mathrm{P} 1-7^{\top}$ were $26.9,27.7,38.2$ and $22.6 \%$, respectively, clearly indicating that strain CCBAU $83401^{\top}$ represents a novel species. Phenotypic characterization of four representative strains, CCBAU $83401^{\top}$, CCBAU 83364 , CCBAU 83345 and CCBAU 83523, showed several distinctive features that differentiated them from closely related species. The 31 strains had identical nodD and nifH genes, which were very similar to those of the bean-nodulating $R$. Iusitanum, Devosia neptuniae and $R$. tropici IIB. Based upon these results, the strains from this study are considered to represent a novel species, for which the name Rhizobium multihospitium sp. nov. is proposed. The DNA G + C content ranged from 65.3 to $66.0 \mathrm{~mol} \%\left(T_{\mathrm{m}}\right)$. The type strain is CCBAU $83401^{\top}\left(=\mathrm{LMG} 23946^{\top}=\mathrm{HAMBI}\right.$ $2975^{\top}$ ), which nodulates Robinia pseudoacacia, but not Leucaena leucocephala, Phaseolus vulgaris, Pisum sativum or Medicago sativa.

Abbreviation: IGS, intergenic spacer.

The GenBank/EMBL/DDBJ accession numbers for the 16S rRNA gene sequences of strains CCBAU 83401 ${ }^{\top}$, CCBAU 83333, CCBAU 83375, CCBAU 83277, CCBAU 83345, CCBAU 83319, CCBAU 83325, CCBAU 83364, CCBAU 83435, CCBAU 83503 and CCBAU 83523 are EF035074, EF035062, EF035065, EF035067, EF035059, EF490013, EF035069, EF490014, EF035070, EF035076 and EF035077, respectively. Those for partial IGS sequences are EF490015, EF050766, EF490016, EF050762, EF050763, EF050764, EF050761, EF490017, EF490018, EF050760 and EF050765, respectively; those for partial g/nll gene sequences are EF490040-EF490050, respectively; for partial recA gene sequences are EF490029-EF490039, respectively; for partial atpD gene sequences are EF490019-EF490024, EU130792 and EF490025-EF490028, respectively; for partial nodD gene sequences are EF490051-EF490056, EF549532 and EF490057-EF490060, respectively; and for partial nifH gene sequences are EF490070, EF490061-EF490065, EF549533 and EF490066-EF490069, respectively.

Dendrograms based on IGS-RFLP fingerprints, SDS-PAGE of proteins and BOX-PCR and phylogenetic trees based on sequences of the 165 rRNA gene, IGS and $\operatorname{atp} D, \operatorname{rec} A, g / n l l$, nodD and nifH genes of the test rhizobial strains and reference strains of recognized Rhizobium species and a table showing the fatty acid profile of strain CCBAU $83401^{\top}$ and those of closely related taxa are available as supplementary material with the online version of this paper. 
Rhizobia are soil bacteria that cause the formation of rootand/or stem-nodules on leguminous plants. Within the nodules, they reduce $\mathrm{N}_{2}$ to ammonia, which can be used by the host plants. In the past two decades, the classification of rhizobia has developed rapidly due mainly to the application of a polyphasic approach and the studies of new rhizobial isolates. At the time of writing, about 50 species have been reported in the four main genera Rhizobium, Sinorhizobium, Mesorhizobium and Bradyrhizobium, and also in other genera including Azorhizobium, Devosia, Methylobacterium, Ochrobactrum and Phyllobacterium in the Alphaproteobacteria, as well as Burkholderia and Cupriavidus in the Betaproteobacteria (Wang et al., 2006). As documented previously, there are more than 19700 leguminous plant species throughout the world, but only few of them have been investigated for their microsymbionts (Allen \& Allen, 1981). As more leguminous species in divergent geographical regions are surveyed it is quite possible that more novel rhizobial species will be discovered.

As reported previously, Xinjiang is an isolated region of China, with unique geographical characteristics and climate conditions (Chen et al., 1997). During a survey of rhizobial resources in Xinjiang, diverse rhizobial populations and complicated relationships among the rhizobial species, host plants and geographical origin were identified. The main findings of these studies were: (i) the description of two rhizobial species, Sinorhizobium xinjiangense (Chen et al., 1988; Peng et al., 2002) and Mesorhizobium tianshanense (Chen et al., 1995); (ii) the recording of rhizobial populations that were genetically and phenotypically different from populations of the same species isolated from other regions (Yan et al., 2000) or strains resistant to high salinity and high $\mathrm{pH}$ (Wei et al., 2004); and (iii) the demonstration that different plants in the same geographical region could share the same rhizobial species for nodulation (Chen et al., 1995). All of these findings implied that the rhizobial populations in Xinjiang have evolved independently and have high potential in searching for novel bacteria.

In our previous study, 111 rhizobial strains isolated from the nodules of wild legumes native to Xinjiang were characterized by using $16 \mathrm{~S}$ rDNA restriction analysis (ARDRA) (Han et al., 2008). The strains showed diverse genetic characteristics, among which 31 strains (Table 1) isolated from Alhagi, Astragalus, Caragana, Halimodendron, Lathyrus, Lotus, Oxytropis, Robinia, Sophora and Vicia species formed a distinctive rDNA type within the genus Rhizobium. With the aim of clarifying their taxonomic relationships, these strains were studied in the present study by using molecular methods. They were maintained in yeast mannitol agar (YMA) at $4{ }^{\circ} \mathrm{C}$ for

Table 1. Isolates and reference strains used in this study

CCBAU, Culture Collection of Beijing Agricultural University, Beijing, PR China.

\begin{tabular}{|c|c|c|}
\hline CCBAU number & Host plant & $\begin{array}{c}\text { Geographical } \\
\text { origin }\end{array}$ \\
\hline \multicolumn{3}{|l|}{ Rhizobium mulithospitium } \\
\hline 83345 & Lotus frondosus & Xinjiang, China \\
\hline $83319,83325,83347,83348,83349$ & Lotus tenuis & Xinjiang, China \\
\hline 83277 & Alhagi toum & Xinjiang, China \\
\hline $83373,83374,83375$ & Astragalus aksuensis & Xinjiang, China \\
\hline $83376,83377,83380$ & Astragalus betetovii & Xinjiang, China \\
\hline $83401^{\mathrm{T}}$ & Halimodendron halodendron & Xinjiang, China \\
\hline 83370 & Oxytropis meinshausenii & Xinjiang, China \\
\hline 83332,83333 & Oxytropis glabra & Xinjiang, China \\
\hline 83283 & Robinia pseudoacacia & Xinjiang, China \\
\hline 83292 & Sophora alopecuriodes & Xinjiang, China \\
\hline $83359,83360,83364$ & Caragana jubata & Xinjiang, China \\
\hline 83434,83435 & Lathyrus odoratus & Xinjiang, China \\
\hline $83500,83501,83503,83504,83523,83524,83525$ & Vicia hirsuta & Xinjiang, China \\
\hline \multicolumn{3}{|l|}{ Reference strains } \\
\hline Rhizobium etli CFN $42^{\mathrm{T}}$ & Phaseolus vulgaris & Mexico \\
\hline R. gallicum USDA $2918^{\mathrm{T}}$ & Phaseolus vulgaris & France \\
\hline R. leguminosarum bv. viciae USDA $2370^{\mathrm{T}}$ & Pisum sativum & USA \\
\hline R. leguminosarum bv. trifolii $162 \mathrm{~K} 68$ & Trifolium pratens & USA \\
\hline R. leguminosarum bv. phaseoli $127 \mathrm{~K} 17$ & Phaseolus vulgaris & USA \\
\hline R. tropici IIA CFN 299 & Phaseolus vulgaris & Brazil \\
\hline R. tropici IIB CIAT $899^{\mathrm{T}}$ & Phaseolus vulgaris & Columbia \\
\hline R. rhizogenes LMG $150^{\mathrm{T}}$ & Phaseolus vulgaris & \\
\hline R. lusitanum $\mathrm{P} 1-7^{\mathrm{T}}$ & Phaseolus vulgaris & Portugal \\
\hline
\end{tabular}


temporary storage and in $20 \%$ glycerol at $-80{ }^{\circ} \mathrm{C}$ for longterm storage.

16S-23S rDNA intergenic spacer (IGS)-RFLP, which is considered to be a useful tool for investigating the relatedness of closely related rhizobial strains (Jensen et al., 1993; Laguerre et al., 1996), was carried out using the primers FGPS1490 (Navarro et al., 1992) and FGPL132' (Ponsonnet \& Nesme, 1994) and the restriction endonucleases MboI, MspI and AluI. The results showed that the test strains formed a cluster with a similarity of $73 \%$, at which all the reference strains for recognized Rhizobium species were distinguished according to their species (see Supplementary Fig. S1, available in IJSEM Online).

SDS-PAGE of whole-cell proteins has been used widely in rhizobial taxonomy (Diouf et al., 2000; Tan et al., 1997; Wang et al., 2007) and is suitable for use to group strains at species level. Methods described previously (Tan et al., 1997; Wang et al., 2006) were applied to extract whole-cell proteins from the 31 test strains and to perform the SDSPAGE analysis. The 31 strains showed 11 distinct protein patterns and formed a cluster at a similarity level of $80 \%$ in the UPGMA dendrogram constructed with the Dice coefficient (see Supplementary Fig. S2 in IJSEM Online), which was quite different from recognized Rhizobium species. Three subclusters could be clearly observed among the test strains.

By using BOX-PCR, fingerprints can be produced that can distinguish closely related isolates, even those of the same species (Vinuesa et al., 1998; Cho \& Tiedje, 2000; Healy et al., 2005; Rademaker et al., 2000). The BOX-PCR analysis was performed by using the method described by Versalovic et al. (1994) and Nick \& Lindström (1994). Among the 31 test strains, 20 BOX patterns were generated, showing that they were not clones (see Supplementary Fig. S3 in IJSEM Online). All the test strains formed a cluster at $71 \%$ similarity, which was obviously separated from all the reference strains in the dendrogram constructed with UPGMA and the Dice coefficient. In accordance with the results from SDS-PAGE, the strains tested formed three distinct subclusters.

Four representative strains, CCBAU $83401^{\mathrm{T}}$, CCBAU 83345, CCBAU 83364 and CCBAU 83523, and eight reference strains of recognized species were characterized comparatively. One hundred and five phenotypic features, including the utilization of sole carbon and nitrogen sources; resistance to antibiotics $(5,50,100$ and $300 \mu \mathrm{g}$ $\left.\mathrm{ml}^{-1}\right)$; tolerance to $\mathrm{NaCl}(1-5.0 \%, \mathrm{w} / \mathrm{v})$; production of catalase, urease, L-phenylalaninase and oxidase; methyl blue reduction, nile blue reduction and nitrate reduction; reaction in litmus milk; and $\mathrm{pH}$ and temperature ranges for growth were examined using methods described previously (Gao et al., 1994). The results showed that the four representative strains had identical features and could be differentiated from recognized Rhizobium species by several characteristics (Table 2).
Table 2. Characteristics that differentiate $R$. mulithospitium sp. nov. and closely related recognized Rhizobium species

Taxa: 1 , R. etli CFN 42 ${ }^{\mathrm{T}} ; 2$, R. leguminosarum USDA $2370^{\mathrm{T}} ; 3, R$. rhizogenes LMG $150^{\mathrm{T}} ; 4$, $R$. tropici IIA CFN 299; 5, R. tropici IIB CIAT $899^{\mathrm{T}}$; 6, R. lusitanum $\mathrm{P} 1-7^{\mathrm{T}} ; 7$, R. mulithospitium (strains CCBAU 83401 ${ }^{\mathrm{T}}, \mathrm{CCBAU}$ 83345, CCBAU 83364 and CCBAU 83523). +, Positive; -, negative.

\begin{tabular}{|c|c|c|c|c|c|c|c|}
\hline Characteristic & 1 & 2 & 3 & 4 & 5 & 6 & 7 \\
\hline \multicolumn{8}{|l|}{ Substrates used as sole carbon source } \\
\hline D-Amygdalin & + & + & + & + & - & + & + \\
\hline D-Arabinose & + & + & - & - & - & + & + \\
\hline Calcium gluconate & - & - & - & - & - & + & + \\
\hline Inulin & - & + & - & - & - & + & - \\
\hline Melezitose & - & - & + & - & - & - & - \\
\hline Sodium pyruvate & - & + & - & + & + & + & + \\
\hline Salicin & + & + & + & - & - & + & + \\
\hline Sodium acetate & + & + & - & - & - & + & - \\
\hline Sodium formate & - & - & - & - & - & - & + \\
\hline D-Sodium gluconate & - & + & - & - & - & + & + \\
\hline Sodium hippurate & - & + & - & - & - & - & - \\
\hline Sorbose & - & - & - & + & - & + & + \\
\hline DL-Arginine & + & - & - & - & - & + & + \\
\hline DL-Aspartic acid & - & + & - & - & - & + & + \\
\hline Glycine & - & - & - & - & - & + & - \\
\hline DL-Proline & + & + & - & - & - & + & + \\
\hline \multicolumn{8}{|l|}{ Substrates used as sole nitrogen source } \\
\hline DL-Alanine & - & - & + & + & + & + & + \\
\hline L-Threonine & - & - & - & - & - & - & + \\
\hline D-Threonine & - & - & - & - & - & - & + \\
\hline \multicolumn{8}{|l|}{ Resistant to $\left(\mu \mathrm{g} \mathrm{ml}^{-1}\right)$ : } \\
\hline Ampicillin (5) & + & + & + & - & + & + & + \\
\hline Ampicillin (50) & + & + & + & - & + & + & + \\
\hline Ampicillin (100) & + & + & - & - & + & + & + \\
\hline Ampicillin (300) & + & + & - & - & - & + & + \\
\hline Chloramphenicol (5) & + & + & + & + & - & + & + \\
\hline Chloramphenicol (50) & + & + & - & - & - & + & + \\
\hline Chloramphenicol (100) & - & - & - & - & - & - & + \\
\hline Erythromycin (50) & - & - & - & - & - & - & + \\
\hline Kanamycin (50) & + & + & + & - & - & + & + \\
\hline Neomycin (50) & + & + & + & + & - & + & + \\
\hline Streptomycin (5) & + & + & + & - & + & + & + \\
\hline Streptomycin (50) & + & + & - & - & + & + & + \\
\hline Streptomycin (100) & + & + & - & - & - & + & + \\
\hline \multicolumn{8}{|l|}{ Other reactions } \\
\hline Nile blue reduction & + & - & + & + & + & + & + \\
\hline Methyl blue reduction & - & - & + & - & + & + & - \\
\hline Acid production in litmus milk & + & + & + & - & + & + & + \\
\hline Alkaline production in litmus milk & & - & - & + & - & - & - \\
\hline Curd in litmus milk & + & - & - & - & + & - & + \\
\hline
\end{tabular}

To clarify the phylogenetic position of this group of strains, strains representing the three subclusters were analysed based on the $16 \mathrm{~S}$ rRNA gene. In this study, almostcomplete 16S rRNA gene sequences of 11 representative strains including CCBAU $83401^{\mathrm{T}}$, CCBAU 83333, CCBAU 83375, CCBAU 83277, CCBAU 83345, CCBAU 83319, 
CCBAU 83325, CCBAU 83364, CCBAU 83435, CCBAU 83503 and CCBAU 83523 (all of them were also included in the subsequent sequence analyses of other genes) were amplified using primers P1 and P6 (Chen et al., 1995) and sequenced directly as described by Hurek et al. (1997). These sequences were compared with those held in the GenBank database. All sequences obtained from this work and from the GenBank database were aligned using CLUSTAL W software (Thompson et al., 1994). The distances were calculated according to the models of Jukes \& Cantor (1969), Kimura two-parameter (Kimura, 1983) and Tajima \& Nei (1984) and Tamura \& Nei (1993). Phylogenetic trees were reconstructed using the neighbour-joining (Saitou \& Nei, 1987), minimum-evolution (Rzhetsky \& Nei, 1993) and maximum-parsimony (Swofford, 1993) methods. Bootstrap analysis was based on 1000 replications. All trees were analysed using the MEGA3 package (Kumar et al., 2004). As no significant topological differences were found among the phylogenetic trees constructed using the different methods, only those trees constructed by using the neighbour-joining method after distance analysis of aligned sequences according to Jukes and Cantor model are shown (and also for the IGS and $a t p D, r e c A$ and $g l n I I$ genes, see below). The $16 \mathrm{~S}$ rRNA gene sequences of the 11 representative test strains were identical and therefore only strains CCBAU $83401^{\mathrm{T}}$, CCBAU 83345, CCBAU 83364 and CCBAU 83523 are shown in the phylogenetic trees (Fig. 1; see also Supplementary Fig. S4 in IJSEM Online). These sequences showed $99.6 \%$ similarity to the $16 \mathrm{~S}$ rRNA gene of Rhizobium tropici IIB CIAT $899^{\mathrm{T}}$, $98.6 \%$ to R. tropici IIA CFN 299, 99.2\% to Rhizobium rhizogenes LMG $150^{\mathrm{T}}$ and $99.4 \%$ to Rhizobium lusitanum $\mathrm{P} 1-7^{\mathrm{T}}$.

It is generally considered that the 16S-23S rRNA gene spacer regions are more abberrant than 16S rRNA genes and are more effective for use among closely related rhizobial strains (Kwon et al., 2005). The 11 representative strains were amplified with the same primers used in IGSRFLP and sequenced using the method for the 16S rRNA gene. At the present time, housekeeping genes for proteincoding interspersing throughout the genome, including atpD, $r e c A$ and $g \ln I I$, are being used increasingly. These genes were used to investigate the phylogeny of bacteria in order to obtain information besides that using the $16 \mathrm{~S}$ rRNA gene (Turner \& Young, 2000; Gaunt et al., 2001; Maggi Solca et al., 2001; Vinuesa et al., 2005a, b; Valverde et al., 2006). In the present study, atpD and recA genes were obtained by using the method of Vinuesa et al. (2005a, b) and the $g \ln I I$ gene by that of Turner \& Young (2000). The amplified sequences were sequenced and analysed as that for $r r s$ and IGS. The sequence similarities of IGS, atpD, $g \ln I I$ and $r e c A$ among the representative strains and reference strains are summarized in Table 3. Phylogenetic trees for each locus are available in Supplementary Fig. S5a-d, in IJSEM Online. The results obtained confirmed the phylogenetic position of these strains within the group $R$. tropici- $R$. rhizogenes $-R$. lusitanum. All these results strongly suggest that this group of strains may belong to a novel species within the $R$. tropici$R$. rhizogenes $-R$. lusitanum phylogenetic branch. In the present study, the 16S rRNA gene was the most conserved among all the sequenced genes or IGS and the proteincoding genes and IGS were more discriminative than the $16 \mathrm{~S}$ rRNA gene. Considering all the sequences, the strains in the novel group formed a phyletic cluster in Rhizobium distinct from recognized species.

DNA-DNA hybridization is considered to be a standard method for use for species definition (Wayne et al., 1987; Graham et al., 1991). In this work, strains CCBAU $83401^{\mathrm{T}}$, CCBAU 83345, CCBAU 83364 and CCBAU 83523 and related reference strains were chosen for DNA-DNA hybridization. Total DNA was extracted from each strain

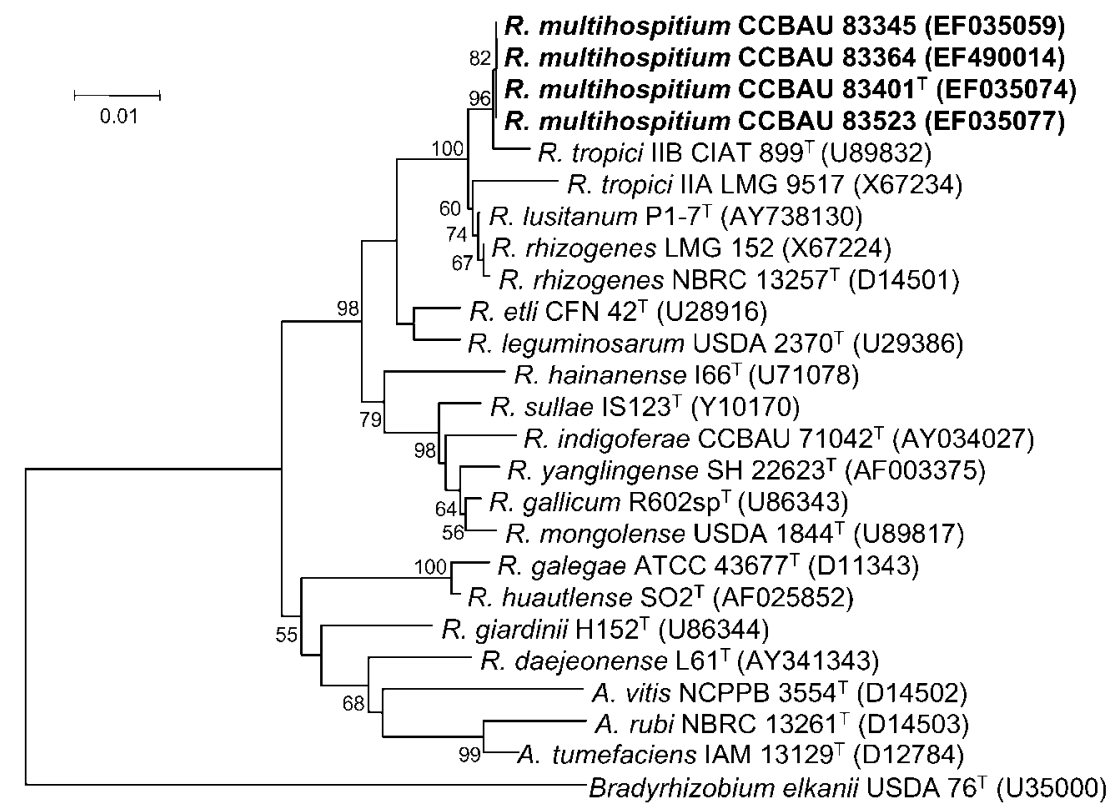

\footnotetext{
Fig. 1. Phylogenetic tree based on $16 \mathrm{~S}$ rRNA gene sequences showing the relationships among $R$. multihospitium sp. nov. and reference strains of recognized Rhizobium species. The neighbour-joining tree was derived from a 16S rRNA gene sequence distance matrix (Jukes-Cantor). Bootstrap confidence levels greater than $50 \%$ are indicated at nodes. GenBank accession numbers are shown in parentheses. Bar, $1 \%$ nucleotide substitutions. An extended neighbour-joining tree is available in Supplementary Fig. S4 in IJSEM Online. A., Agrobacterium.
} 
by using the method of Marmur (1961) and DNA-DNA hybridization was performed using the spectrophotometric method (De Ley et al., 1970). The DNA-DNA relatedness among strain CCBAU $83401^{\mathrm{T}}$ and the other three strains in the novel group ranged from 80.8 to $100 \%$, indicating that they represent the same genomic species. The DNA-DNA relatedness values between strain CCBAU $83401^{\mathrm{T}}$ and $R$. tropici IIB CIAT $899^{\mathrm{T}}, R$. tropici IIA CFN 299, $R$. rhizogenes LMG $150^{\mathrm{T}}$, R. lusitanum P1-7 ${ }^{\mathrm{T}}$, R. etli CFN $42^{\mathrm{T}}$ and $R$. leguminosarum USDA $2370^{\mathrm{T}}$ were $26.9,27.7,38.2,22.6$, 18.5 and $18.4 \%$, respectively. These results indicated that the genomic species represented by strain CCBAU $83401^{\mathrm{T}}$ was different from recognized species based on the recommendation of a threshold value of $70 \%$ DNADNA relatedness for species definition (Wayne et al., 1987; Graham et al., 1991). The G+C content of the DNA was measured using the thermal denaturation method of Marmur \& Doty (1962), with E. coli K-12 as a standard. The DNA G+C content varied between 65.3 and $66.0 \mathrm{~mol} \%$, in the range for Rhizobium (Jordan, 1984).

The symbiotic property is an important feature of rhizobia and the symbiotic genes (nod and nif) are adaptive genes that in many cases have an evolutionary history independent of the other genes in the genome (Wang et al., 2007). The comparison of their phylogenies with those derived from housekeeping genes may reveal events of lateral gene transfer among rhizobia (Haukka et al., 1998). In the present study, partial nodD and nifH genes of the representative strains were amplified and sequenced as described previously (Rivas et al., 2002). Interestingly, the sequences of both nodD and nifH among all the 11 strains were identical and had $100 \%$ sequence similarities with those of R. lusitanum $\mathrm{P} 1-7^{\mathrm{T}}$ and Devosia neptuniae $\mathrm{J} 1^{\mathrm{T}}$, and $98.0 \%$ with that of R. tropici IIB CIAT $899^{\mathrm{T}}$ for nodD, and $100 \%$ similarities with those of the three strains for nifH (see Supplementary Fig. S6 in IJSEM Online). These results demonstrated that the nodD and nifH genes might have the same origin in this novel group and the species $R$. lusitanum and Devosia neptuniae, and are similar to those of $R$. tropici.
Cross-nodulation tests were performed among the 11 representative strains with the hosts of origin or related hosts Alhagi sparsifolia, Astragalus membranaceus, Caragana korshinskii, Glycyrrhiza uralensis, Halimodendron halodendron, Lathyrus odoratus, Lotus corniculatus, Oxytropis glabra, Robinia pseudoacacia, Sophora alopecuroides, Vicia angustifolia, Vicia multicaulis, Vicia sepium, and the recommended plant species Leucaena leucocephala, Phaseolus vulgaris, Pisum sativum and Medicago sativa (Graham et al., 1991). Only strain CCBAU $83401^{\mathrm{T}}$ formed nodules on Robinia pseudoacacia in addition to its original host, Halimodendron halodendron. Because these strains were isolated from legumes grown in alkaline soils with high salt concentration, they may require special soil conditions to form nodules.

Based on all the results obtained in this study, we believe that the 31 strains represent a novel species of the genus Rhizobium. According to the current criteria of rhizobial species description (Graham et al., 1991; Wayne et al., 1987), we propose a novel species, Rhizobium multihospitium, for the strains in the group. This species can be differentiated from closely related Rhizobium species by several phenotypic characteristics (Table 2) and fatty acid composition (see Supplementary Table S1 in IJSEM Online).

\section{Description of Rhizobium multihospitium sp. nov.}

Rhizobium multihospitium (mul.ti.ho.spi'ti.um. L. adj. multus many, numerous; L. n. hospes -itis, he who entertains a stranger, a host; N.L. gen. pl. n. multihospitium of numerous hosts, referring to the isolation of the bacterium from various legume species).

Cells are Gram-negative, aerobic, motile, non-sporeforming rods, $0.3-0.5 \mu \mathrm{m}$ wide and $1-3 \mu \mathrm{m}$ long. Colonies on YMA are circular, convex, white, opaque and usually have a diameter of 1-2 mm within 2-3 days at $28{ }^{\circ} \mathrm{C}$. Grows on YMA with $2 \% \mathrm{NaCl}$. Growth occurs at $12-37{ }^{\circ} \mathrm{C}$ and $\mathrm{pH} 5-10$ on YMA. Utilizes D-amygdalin, Darabinose, calcium gluconate, meso-erythritol, D-fructose,

Table 3. Sequence similarities (\%) of housekeeping and symbiotic genes among strain CCBAU $83401^{\top}$ and the other 10 representative strains of the novel group and reference strains of recognized species

NA, Not available; -, not analysed.

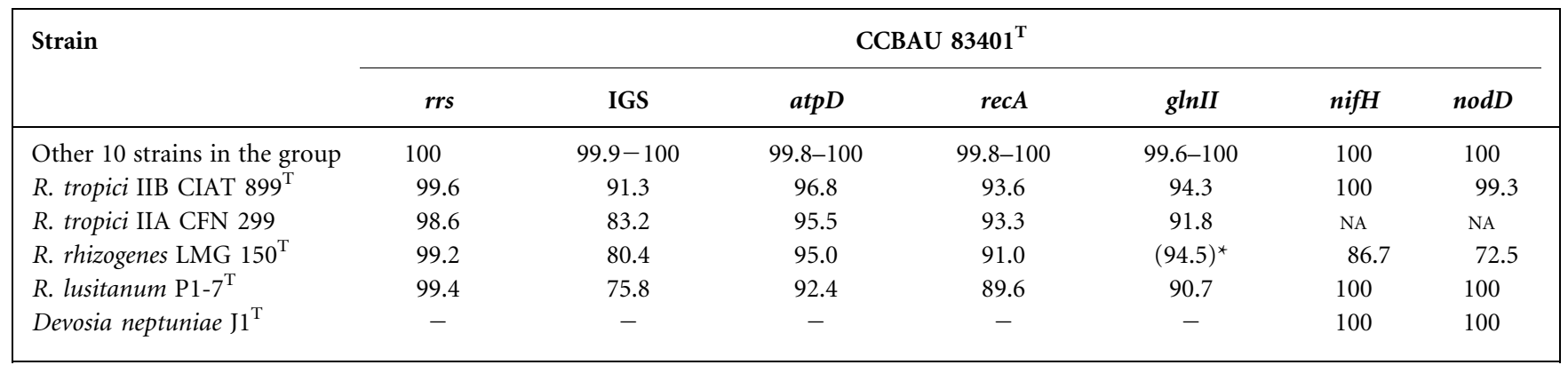

*Value was obtained by comparison with $R$. rhizogenes LMG 152. 
(+)-D-galactose, D-glucose, inositol, lactose, sodium malate, maltose, D-mannose, turanose, sodium pyruvate, raffinose, L-rhamose, salicin, sodium citrate, sodium formate, D-sodium gluconate, sodium succinate, sorbose, sucrose, trehalose, D-xylose, DL-arginine, DL-aspartic acid and DL-proline as sole carbon sources, and DL-alanine, Larginine, (+)-L-aspartic acid, L-cystine, D-glutamic acid, (+)-L-glutamic acid, hypoxanthine, L-isoleucine, L-lysine, L-phenylalanine, D-threonine, L-valine, glycine, L-threonine and L-hydroxyproline as sole nitrogen sources. Does not use adipic acid, inulin, melezitose, sodium acetate, sodium hippurate, soluble starch, syringic acid, sodium tartrate, vanillic acid, glycine or L-methionine as sole carbon sources. Resistant to kanamycin $\left(50 \mu \mathrm{g} \mathrm{ml}^{-1}\right)$, erythromycin $\left(50 \mu \mathrm{g} \mathrm{ml}^{-1}\right)$, neomycin $\left(50 \mu \mathrm{g} \mathrm{ml}^{-1}\right)$, streptomycin $\left(100 \mu \mathrm{g} \mathrm{ml}{ }^{-1}\right)$, chloramphenicol $\left(100 \mu \mathrm{g} \mathrm{ml}^{-1}\right)$ and ampicillin $\left(300 \mu \mathrm{g} \mathrm{ml}^{-1}\right)$. Catalase, urease and oxidase are present, but not L-phenylalaninase. Nitrate is not reduced and reduction of methyl blue is not observed. Nile blue reduction is observed. Acid and curd are produced in litmus milk. The $\mathrm{G}+\mathrm{C}$ content of the DNA ranges from 65.3 to $66.0 \mathrm{~mol} \%$.

The type strain, CCBAU $83401^{\mathrm{T}}\left(=\mathrm{LMG} 23946^{\mathrm{T}}=\right.$ HAMBI $\left.2975^{\mathrm{T}}\right)$, was isolated from nodules of legumes native of Xinjiang, China.

\section{Acknowledgements}

We thank Professor Ge Hong Wei and Professor Fu Suo Zhang for their kind help with the seed and nodule collections, and our colleagues Xue Rui Yan, Li Li Han and Chao Xin Man as well as Hai Sheng Wang and Yu Shi for their help in the experiments and data analysis. This work was supported by the National Basic Research Program of China (2006CB100206), National Program for Basic S \& $\mathrm{T}$ Platform Construction (2005DKA21201-10) and the National Natural Science Foundation of China (30670001 and 30400001). E. T. W. was supported by grants CGPI20060213 and CGPI20070538 authorized by IPN, Mexico.

\section{References}

Allen, O. N. \& Allen, E. K. (1981). The Leguminosae. A Source Book of Characteristics, Uses and Nodulation. Madison, USA: University of Wisconsin Press.

Chen, W. X., Yan, G. H. \& Li, J. L. (1988). Numerical taxonomy study of fast-growing soybean rhizobia and a proposal that Rhizobium fredii be assigned to Sinorhizobium gen. nov. Int J Syst Bacteriol 38, 392-397.

Chen, W., Wang, E., Wang, S., Li, Y., Chen, X. Q. \& Li, Y. (1995). Characteristics of Rhizobium tianshanense sp. nov., a moderately and slowly growing root nodule bacterium isolated from an arid saline environment in Xinjiang, People's Republic of China. Int J Syst Bacteriol 45, 153-159.

Chen, W. X., Tan, Z. Y., Gao, J. L., Li, Y. \& Wang, E. T. (1997). Rhizobium hainanense sp. nov., isolated from tropical legumes. Int $J$ Syst Bacteriol 47, 870-873.

Cho, J.-C. \& Tiedje, J. M. (2000). Biogeography and degree of endemicity of fluorescent Pseudomonas strains in soil. Appl Environ Microbiol 66, 5448-5456.
De Ley, J., Cattoir, H. \& Reynaerts, A. (1970). The quantitative measurement of DNA hybridization from renaturation rates. Eur $J$ Biochem 12, 133-142.

Diouf, A., de Lajudie, P., Neyra, M., Kersters, K., Gillis, M., MartínezRomero, E. \& Gueye, M. (2000). Polyphasic characterization of rhizobia that nodulate Phaseolus vulgaris in West Africa (Senegal and Gambia). Int J Syst Evol Microbiol 50, 159-170.

Gao, J. L., Sun, J. G., Li, Y., Wang, E. T. \& Chen, W. X. (1994). Numerical taxonomy and DNA relatedness of tropical rhizobia isolated from Hainan province of China. Int J Syst Bacteriol 44, 151158.

Gaunt, M. W., Turner, S. L., Rigottier-Gois, L., Lloyd-Macgilp, S. A. \& Young, J. P. W. (2001). Phylogenies of atpD and recA support the small subunit rRNA-based classification of rhizobia. Int J Syst Evol Microbiol 51, 2037-2048.

Graham, P. H., Sadowsky, M. J., Keyser, H. H., Barnet, Y. M., Bradley, R. S., Cooper, J. E., De Ley, D. J., Jarvis, B. D. W., Roslycky, E. B. \& other authors (1991). Proposed minimal standards for the description of new genera and species of root- and stem-nodulating bacteria. Int J Syst Bacteriol 41, 582-587.

Han, T. X., Wang, E. T., Han, L. L., Chen, W. F., Sui, X. H. \& Chen, W. X. (2008). Molecular diversity and phylogeny of rhizobia associated with wild legumes native to Xinjiang, China. Syst Appl Microbiol (in press).

Haukka, K., Lindström, K. \& Young, J. P. (1998). Three phylogenetic groups of nodA and nifH genes in Sinorhizobium and Mesorhizobium isolates from leguminous trees growing in Africa and Latin America. Appl Environ Microbiol 64, 419-426.

Healy, M., Huong, J., Bittner, T., Lising, M., Frye, S., Raza, S., Schrock, R., Manry, J., Renwick, A. \& other authors (2005). Microbial DNA typing by automated repetitive-sequence-based PCR. J Clin Microbiol 43, 199-207.

Hurek, T., Wagner, B. \& Reinhold-Hurek, B. (1997). Identification of $\mathrm{N}_{2}$-fixing plant- and fungus-associated Azoarcus species by PCRbased genomic fingerprints. Appl Environ Microbiol 63, 4331-4339.

Jensen, M. A., Webster, J. A. \& Straus, N. (1993). Rapid identification of bacteria on the basis of polymerase chain reaction-amplified ribosomal DNA spacer polymorphisms. Appl Environ Microbiol 59, 945-952.

Jordan, D. C. (1984). Family III. Rhizobiaceae Conn 1938, $321^{\mathrm{AL}}$. In Bergey's Manual of Systematic Bacteriology, vol. 1, pp. 234-242. Edited by N. R. Krieg \& J. G. Holt. Baltimore: Williams \& Wilkins.

Jukes, T. H. \& Cantor, C. R. (1969). Evolution of protein molecules. In Mammalian Protein Metabolism, vol. 3, pp. 21-132. Edited by H. N. Munro. New York: Academic Press.

Kimura, M. (1983). The Neutral Theory of Molecular Evolution. Cambridge: Cambridge University Press.

Kumar, S., Tamura, K. \& Nei, M. (2004). MEGA3: Integrated software for Molecular Evolutionary Genetics Analysis and sequence alignment. Brief Bioinform 5, 150-163.

Kwon, S. W., Park, J. Y., Kim, J. S., Kang, J. W., Cho, Y. H., Lim, C. K., Parker, M. A. \& Lee, G. B. (2005). Phylogenetic analysis of the genera Bradyrhizobium, Mesorhizobium, Rhizobium and Sinorhizobium on the basis of $16 \mathrm{~S}$ rRNA gene and internally transcribed spacer region sequences. Int J Syst Evol Microbiol 55, 263-270.

Laguerre, G., Mavingui, P., Allard, M. R., Charnay, M. P., Louvrier, P., Mazurier, S. l., Rigottier-Gois, L. \& Amarger, N. (1996). Typing of rhizobia by PCR DNA fingerprinting and PCR-restriction fragment length polymorphism analysis of chromosomal and symbiotic gene regions: application to Rhizobium leguminosarum and its different biovars. Appl Environ Microbiol 62, 2029-2036. 
Maggi Solca, N., Bernasconi, M. V., Valsangiacomo, C., Van Doorn, L. J. \& Piffaretti, J. C. (2001). Population genetics of Helicobacter pylori in the southern part of Switzerland analysed by sequencing of four housekeeping genes $(a t p D, g \ln A, \operatorname{sco} B$ and $r e c A)$, and by $v a c A, \operatorname{cag} A$, iceA and IS605 genotyping. Microbiology 147, 1693-1707.

Marmur, J. (1961). A procedure for the isolation of deoxyribonucleic acid from microorganisms. J Mol Biol 3, 208-218.

Marmur, J. \& Doty, P. (1962). Determination of the base composition of deoxyribonucleic acid from its thermal denaturation temperature. J Mol Biol 5, 109-118.

Navarro, E., Simonet, P., Normand, P. \& Bardin, R. (1992). Characterization of natural populations of Nitrobacter spp. using PCR/RFLP analysis of the ribosomal intergenic spacer. Arch Microbiol 157, 107-115.

Nick, G. \& Lindström, K. (1994). Use of repetitive sequences and the polymerase chain reaction to fingerprint the genomic DNA of $R$. galegae strains and to identify the DNA obtained by sonicating liquid cultures and root nodules. Syst Appl Microbiol 17, 265-273.

Peng, G. X., Tan, Z. Y., Wang, E. T., Reinhold-Hurek, B., Chen, W. F. \& Chen, W. X. (2002). Identification of isolates from soybean nodules in Xinjiang region as Sinorhizobium xinjiangense and genetic differentiation of S. xinjiangense from Sinorhizobium fredii. Int J Syst Evol Microbiol 52, 457-462.

Ponsonnet, C. \& Nesme, X. (1994). Identification of Agrobacterium strains by PCR-RFLP analysis of pTi and chromosomal regions. Arch Microbiol 161, 300-309.

Rademaker, J. L., Hoste, B., Louws, F. J., Kersters, K., Swings, J., Vauterin, L., Vauterin, P. \& de Bruijn, F. J. (2000). Comparison of AFLP and rep-PCR genomic fingerprinting with DNA-DNA homology studies: Xanthomonas as a model system. Int J Syst Evol Microbiol 50, 665-677.

Rivas, R., Velázquez, E., Willems, A., Vizcaíno, N., Subba-Rao, N. S., Mateos, P. F., Gillis, M., Dazzo, F. B. \& Martínez-Molina, E. (2002). A new species of Devosia that forms a unique nitrogen-fixing root nodule symbiosis with the aquatic legume Neptunia natans (L. f.) Druce. Appl Environ Microbiol 68, 5217-5222.

Rzhetsky, A. \& Nei, M. (1993). Theoretical foundation of the minimum-evolution method of phylogenetic inference. Mol Biol Evol 10, 1073-1095.

Saitou, N. \& Nei, M. (1987). The neighbor-joining method: a new method for reconstructing phylogenetic trees. Mol Biol Evol 4, 406-425.

Swofford, D. L. (1993). PAUP: Phylogenetic Analysis Using Parsimony, version 3.1.1. Champaign, IL: Illinois Natural History Survey.

Tajima, F. \& Nei, M. (1984). Estimation of evolutionary distance between nucleotide sequences. Mol Biol Evol 1, 269-285.

Tamura, K. \& Nei, M. (1993). Estimation of the number of nucleotide substitutions in the control region of mitochondrial DNA in humans and chimpanzees. Mol Biol Evol 10, 512-526.

Tan, Z. Y., Xu, X. D., Wang, E. T., Gao, J. L., Martínez-Romero, E. \& Chen, W. X. (1997). Phylogenetic and genetic relationships of Mesorhizobium tianshanense and related rhizobia. Int J Syst Bacteriol 47, 874-879.
Thompson, J. D., Higgins, D. G. \& Gibson, T. J. (1994). Clustal W: improving the sensitivity of progressive multiple sequence alignment through sequence weighting, position-specific gap penalties and weight matrix choice. Nucleic Acids Res 22, 4673-4680.

Turner, S. L. \& Young, J. P. (2000). The glutamine synthetases of rhizobia: phylogenetics and evolutionary implications. Mol Biol Evol 17, 309-319.

Valverde, A., Igual, J. M., Peix, A., Cervantes, E. \& Velazquez, E. (2006). Rhizobium lusitanum sp. nov., a bacterium that nodulates Phaseolus vulgaris. Int J Syst Evol Microbiol 56, 2631-2637.

Versalovic, J., Schneider, M., de Bruijn, F. J. \& Lupski, J. R. (1994). Genomic fingerprinting of bacteria using repetitive sequence-based polymerase chain reaction. Methods Mol Cell Biol 5, 25-40.

Vinuesa, P., Rademaker, J. L., de Bruijn, F. J. \& Werner, D. (1998). Genotypic characterization of Bradyrhizobium strains nodulating endemic woody legumes of the Canary Islands by PCR-restriction fragment length polymorphism analysis of genes encoding 16S rRNA and 16S-23S rDNA intergenic spacers, repetitive extragenic palindromic PCR genomic fingerprinting, and partial $16 \mathrm{~S} \mathrm{rDNA}$ sequencing. Appl Environ Microbiol 64, 2096-2104.

Vinuesa, P., Silva, C., Lorite, M. J., Izaguirre-Mayoral, M. L., Bedmar, E. J. \& Martínez-Romero, E. (2005a). Molecular systematics of rhizobia based on maximum likelihood and Bayesian phylogenies inferred from $r r s, a t p D, r e c A$ and $n i f H$ sequences, and their use in the classification of Sesbania microsymbionts from Venezuelan wetlands. Syst Appl Microbiol 28, 702-716.

Vinuesa, P., Silva, C., Werner, D. \& Martínez-Romero, E. (2005b). Population genetics and phylogenetic inference in bacterial molecular systematics: the roles of migration and recombination in Bradyrhizobium species cohesion and delineation. Mol Phylogenet Evol 34, 29-54.

Wang, F. Q., Wang, E. T., Zhang, Y. F. \& Chen, W. X. (2006). Characterization of rhizobia isolated from Albizia spp. in comparison with microsymbionts of Acacia spp. and Leucaena leucocephala grown in China. Syst Appl Microbiol 29, 502-517.

Wang, F. Q., Wang, E. T., Liu, J., Chen, Q., Sui, X. H., Chen, W. F. \& Chen, W. X. (2007). Mesorhizobium albiziae sp. nov., a novel bacterium nodulating Albizia kalkora in a subtropical region of China. Int J Syst Evol Microbiol 57, 1192-1199.

Wayne, L. G., Brenner, D. J., Colwell, R. R., Grimont, P. A. D., Kandler, O., Krichevsky, M. I., Moore, L. H., Moore, W. E. C., Murray, R. G. E. \& other authors (1987). International Committee on Systematic Bacteriology. Report of the ad hoc committee on reconciliation of approaches to bacterial systematics. Int J Syst Bacteriol 37, 463-464.

Wei, W., Jiang, J., Li, X., Wang, L. \& Yang, S. S. (2004). Isolation of salt-sensitive mutants from Sinorhizobium meliloti and characterization of genes involved in salt tolerance. Lett Appl Microbiol 39, 278-283.

Yan, A. M., Wang, E. T., Kan, F. L., Tan, Z. Y., Sui, X. H., ReinholdHurek, B. \& Chen, W. X. (2000). Sinorhizobium meliloti associated with Medicago sativa and Melilotus spp. in arid saline soils in Xinjiang, China. Int J Syst Evol Microbiol 50, 1887-1891. 